Agata WALCZAK ${ }^{1}$, Daniel PIENIAK ${ }^{2}$, Renata KAMOCKA-BRONISZ ${ }^{1}$

${ }^{1}$ The Main School of Fire Service (Szkota Gtówna Stużby Pożarniczej)

${ }^{2}$ University of Economics and Innovations in Lublin (Wyższa Szkoła Ekonomii i Innowacji w Lublinie)

\title{
RELIABILITY AND FAILURE STUDIES OF FIREFIGHTERS' HELMETS IN SIMULATED OPERATIONAL CONDITIONS
}

\section{Badania niezawodności i uszkodzeń hełmów strażackich w warunkach symulowanych narażeń operacyjnych}

\begin{abstract}
The aim of the study was to determinate the fracture mechanism of firefighters' helmets caused by the impact load in simulated operational conditions. Moreover the aim of the study was to assess the reliability of the personal protective equipment. Tests were conducted with the use of the drop tower system. On each type of helmet 5 impact tests were performed. The active force corresponding to impact energy of $60 \mathrm{~J}$ and the passive force (force in the place of the neck spine) was registered. Based on the results, it can be statement that helmets' structure influences their reliability and values of the active and passive forces. Additionally, the majority of tested helmets exceeded the acceptable threshold values of passive force.
\end{abstract}

Keywords: firefigher's helmet, dynamic loading, impact test, reliability, operational conditions, limit and critical loads of the neck spine

Streszczenie: Celem badań było określenie mechanizmu niszczenia hełmów strażackich spowodowanego obciązeniem udarowym w symulowanych warunkach narażeń operacyjnych, a także ocena niezawodności sprzętu ochrony indywidualnej. Testy przeprowadzono z wykorzystaniem młota udarowego opadowego. Na kazdym typie hetmu przeprowadzono po 5 testów udarowych. Rejestrowano site czynna odpowiadająca energii uderzenia 60 Joraz sitę bierna (siłę w miejscu kręgostupa szyjnego). Na podstawie wyników można stwierdzić, że konstrukcja hetmów i ich stan wpływaja na ich niezawodność $i$ wartości sit czynnych i biernych. W przypadku większości badanych hetmów przekroczono dopuszczalne wartości progowe sił biernych.

Słowa kluczowe: hełm strażacki, obciążenie dynamiczne, badanie udarowe, niezawodność, warunki operacyjne, dopuszczalne i krytyczne obciążenia kręgosłupa szyjnego 


\section{Introduction}

Main threats occurring during the firefighting and rescue actions come from the thermal and mechanical exposures. Mechanical threats can be divided into static and dynamic. Dynamic load is specific for a short term, impulsive action of high amplitude. In case of firefighers' helmets the most often are single impact loads, generated as a result of impact of the detached structural element on the helmet [3,7], direct impact on the sticking rods, hitting invisible obstacle or impacts of the pieces during the explosion [17]. Firefighter's head is mainly subject to mechanical threats. Firefighter's personal protective equipment are usually exposed to low velocity [1] and low energy [5] impacts. Main function of the fire helmet is absorbance of the mechanical forces acting in the direction of the rescuer's head and its dissipation $[6,8]$. The process is based on the change of kinetic energy into other form of energy in a controlled and stable way.

Shell of firefighter's helmet as an element of the external structure takes the impact absorbing part of energy. It protects against penetration of the sharp elements towards the head. Cushioning insert placed under the shell also absorbs the energy of mechanical impact, mainly due to slow, long deformation [10]. Such mechanism promotes increased deformation work and effective dissipation of impact energy. Helmet should also reduce accelerations [9] and redistribution of forces in the direction of the rescuer's body [8, 13]. Fire helmets are designed to prevent the central contact between helmet's structure and head, which could lead to head injuries [20]. Therefore, the part of forces is redistributed by the helmet's structure towards the body. In case of point central force a neck spine can be exposed to the compressive load. Based on MES analysis presented in [20] it has been demonstrated that the limit of human's neck spine strength in case of compressive exposure is about $3 \mathrm{kN}$. According to other literature sources the value is higher and is about $5 \mathrm{kN}$ $[2,4]$. However, it should be stressed that the reference values are estimates.

The aim of the study was to determine the fracture mechanism and reliability of firefighters' helmets. The focus was put on active and passive forces' distributions, values and time of exposures.

\section{Research objects and method}

For the studies four fire helmets were used: three models produced by KZPT Kalisz (Poland) originating from different periods of production and one Pacific Helmets Ltd. (New Zealand). KZPT helmets were used by the officer cadets from The Main School of Fire Services, and Pacific F7 by the rescuer form the Warsaw firefighting and rescue unit (FRU) (tab. 1). 
Table 1

Firefighting helmets applied in the studies

\begin{tabular}{||l|l|l|l|l||}
\hline $\begin{array}{l}\text { Photographs of } \\
\text { tested helmets }\end{array}$ & $\begin{array}{l}\text { Calisia Vulcan } \\
\text { CV 102 }\end{array}$ & AK-06 & ZS-03 & Pacific F7 M4 \\
\hline Name/Type & $\begin{array}{l}\text { Kaliskie Zakłady } \\
\text { Przemysłu } \\
\text { Terenowego } \\
\text { (KZPT), } \\
\text { Poland }\end{array}$ & $\begin{array}{l}\text { Kaliskie Zakłady } \\
\text { Przemysłu } \\
\text { Terenowego } \\
\text { (KZPT), } \\
\text { Poland }\end{array}$ & $\begin{array}{l}\text { Kaliskie Zakłady } \\
\text { Przemysłu } \\
\text { Terenowego } \\
\text { (KZPT), } \\
\text { Poland }\end{array}$ & $\begin{array}{l}\text { Pacific Helmets } \\
\text { Ltd., } \\
\text { New Zeland }\end{array}$ \\
\hline $\begin{array}{l}\text { Maintenance } \\
\text { status }\end{array}$ & $\begin{array}{l}\text { new helmets, not } \\
\text { used }\end{array}$ & $\begin{array}{l}\text { used helmets, } \\
\text { prod. year 2009 }\end{array}$ & $\begin{array}{l}\text { used helmets, } \\
\text { prod. year 2003 }\end{array}$ & $\begin{array}{l}\text { used helmets, } \\
\text { prod. year 2007 }\end{array}$ \\
\hline \hline
\end{tabular}

Studies were conducted in laboratory conditions. Dedicated equipment support with model of the head and additional force sensor rigid mounted under the model in a place of the neck spine was used (fig. 1). Energy of the central impact was assumed at $60 \mathrm{~J}$ according to Baszczyński [2]. A striker ended with semi-sphere with diameter of $20 \mathrm{~mm}$ and weight of $0.54 \mathrm{~kg}$ was used. The study was conducted with the drop tower impact system DPFtest 1000. On each type of helmet 5 impact tests ( 1 impact in 5 points) were performed according to recommendations of the technical standard PN-EN 443:2008 entitled "Helmets for firefighting in buildings and other structures" [16]. Five limit values of the passive force were taken into account: 1000, 2000, 3000, 4000, $5000 \mathrm{~N}$. 


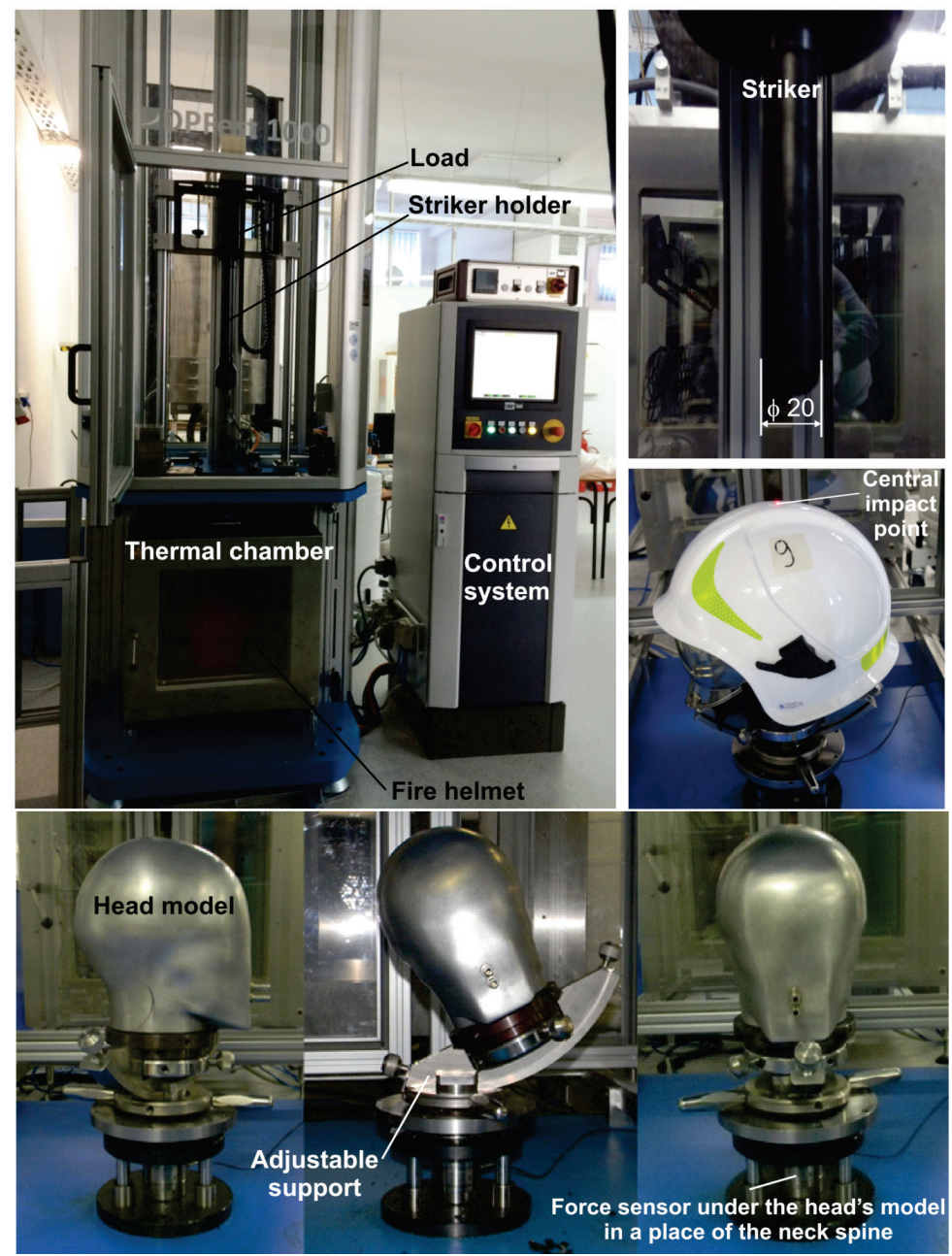

Fig. 1. Test stand for fire helmets testing under dynamic mechanical (impact) loads

\section{Test results and analysis}

Selected results are presented in charts. In figures characteristics of active force (on the striker) and passive (support head's model, at the neck spine) with regards to striker displacement (fig. 2) and time (fig. 3) are shown. For the comparative purposes, in the figures a value of critical force of $5 \mathrm{kN}$ according to [2] has been marked. In figure 4 photos of helmets' failures are presented.

The graphs (fig. 2, 3) present results of central impact on helmets. The obtained values and courses of forces are varied. The deformation of helmets is connected with elastic and 
plastic deformation of helmets' shell, absorber and, to a lesser extent, other elements. Active force graphs (i.e. on the striker side), which are marked by blue curves, are mainly influenced by the helmet shell response. In the first stage of the course of curves, the influence of strengthening (peak in the force graphs) is seen, especially on curves referring to AK-06, ZS-03 and F7 M4 helmets (fig. 2). Then decohesion of the shell's material occurs. It result in the shell cracks (fig. 4). In case of the CV102 helmet the area of cracks was the lowest, it can be connected with the lowest value of the active force peak. In this area, the maximum force value can be referred to the shell strength. The shell of the CV 102 helmet is made in injection technology, it consists of polymer composite strengthened by short glass fibers (Ultramid, BASF). The maximum value of force, in this area of graph, is around $2000 \mathrm{~N}$. Whereas the mean value of impact bending strength of the material is around $400 \mathrm{~N}$ [15]. Observations of active force curves indicate that the ZS-03 shell helmet is characterized by the highest dynamic strength. The shell of this helmet is made of structural composite, a laminate, in which the strengthening is made of a glass fibre fabric. The surface area of ZS-03 shell cracks was the largest but the damage deep was the lowest. It is seen on damage observation (fig. 4) and on the graph by the value of displacement on the abscissa axis. The second stage of the active forces course is similar to monotone.
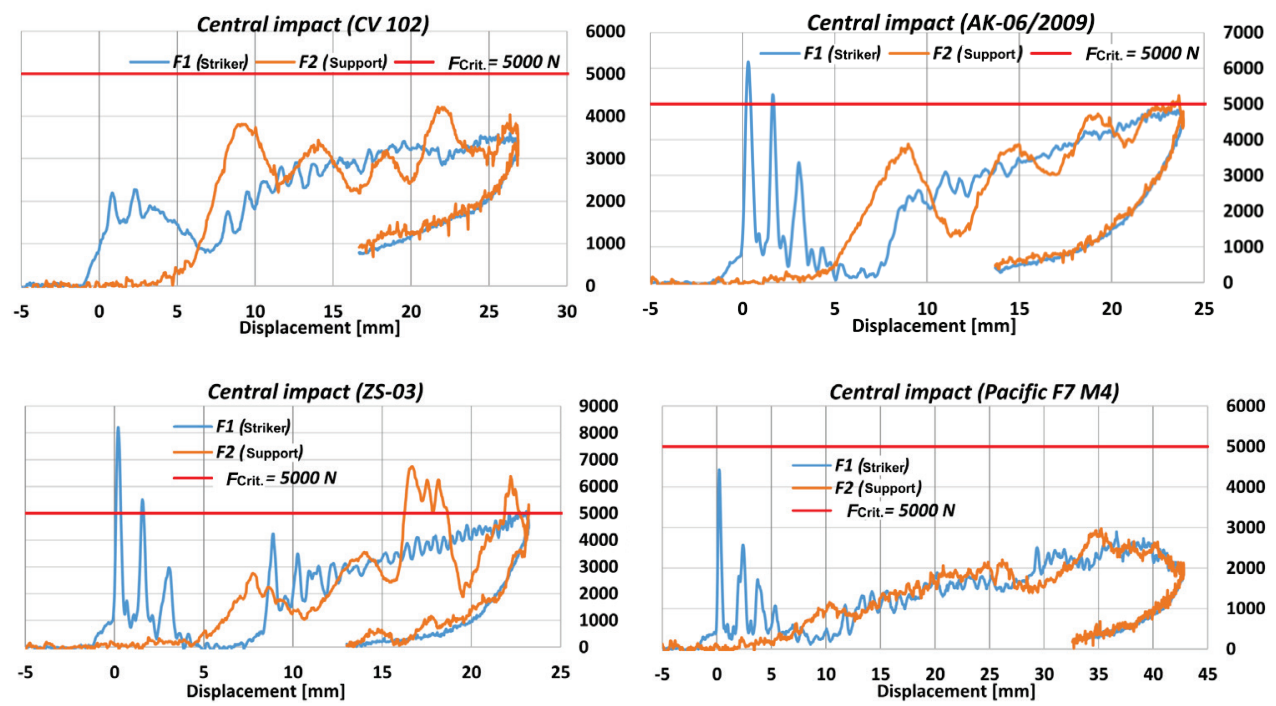

Fig. 2. Characteristics of active and passive forces with regards to displacement during central impact in the helmet

The plateau which indicates that the load was taken up by the energy absorber is clearly seen. Absorbers used in fire helmets are made of polymer foams [18]. Plateau is described as the quasi-linear course of the stress-strain curve [15]. The longer plateau means the higher absorption and dissipation of absorber under impact. The longest plateau was 
observed in the case of the F7 M4 helmet. The length of plateau of all KZPT manufacturer's helmets was similar.

The passive force course is influenced by the force redistribution by the helmet and head model. Force redistribution is connected with the impact energy which is absorbed by helmet. Values of passive force curves clearly increase after decrease of the active force peak. At the first stage of the passive force growth has monotonic character, it seems that it is connected with the rigidity of fire helmet. The highest initial increase of the passive force was characterized by the newest among study objects, CV 102 helmet. Whereas, further the course of the force is similar to sinusoidal wave. It can be related with the action of mass forces in the measuring system and the movement of impact wave [14]. On the graph (fig. 2) the number of positive amplitudes of the mechanical wave ranged from 3 (F7 M4) to 5 (CV 102). The highest value of a wave amplitude on the passive force curves was observed in the case of the ZS-03 helmet. It seems that the helmet has the lowest damping capacity. It is among study objects, the oldest type of helmet manufactured by KZPT. It must be highlighted that in case of ZS-03 and AK-06 helmets passive forces exceeded the value of critical force. For F7 M4 helmet the lowest values of the passive force were obtained.
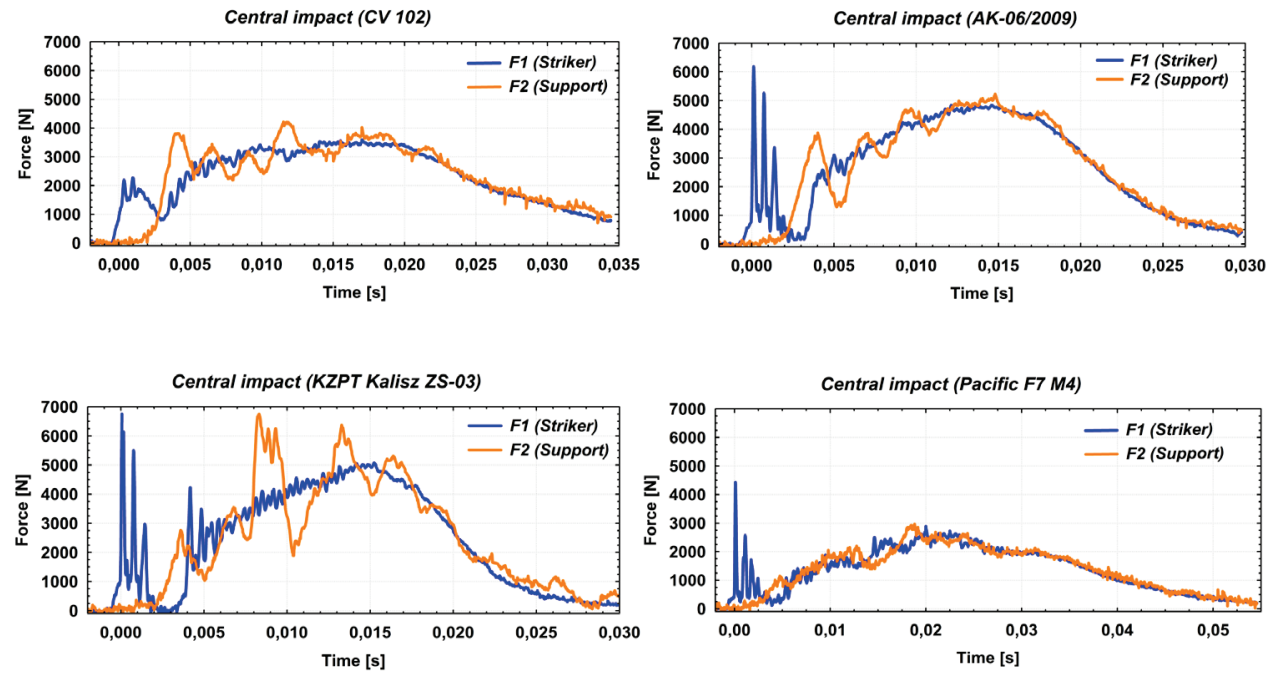

Fig. 3. Characteristics of active and passive forces with regards to time during central impact in the helmet

Analysis of the graphs presented in fig. 3 allows the assessment of the duration of the force impulse that affects the helmet. Long duration of the force impulse is unfavourable. It is reflect, among other in the Head Injury Criterion (HIC) criterion. It is considered as a measure of head injury tolerance according to [12]. The relationship between the duration of force impulse and neck spine injures was not demonstrated. In the authors' own research, 
the longest duration of the force impulse was observed in the case of the F7 M4 helmet. In the case of KZPT helmets the duration of the force impulse was similar.

It should be noted that in case of F7 M4 and AK-06 helmets, the shell was perforated by a striker (fig. 4). Such failure is very dangerous for a firefighter. The situation is the worst in the case of F7 M4 helmet in this respect. The striker moved to a depth of about $43 \mathrm{~mm}$.

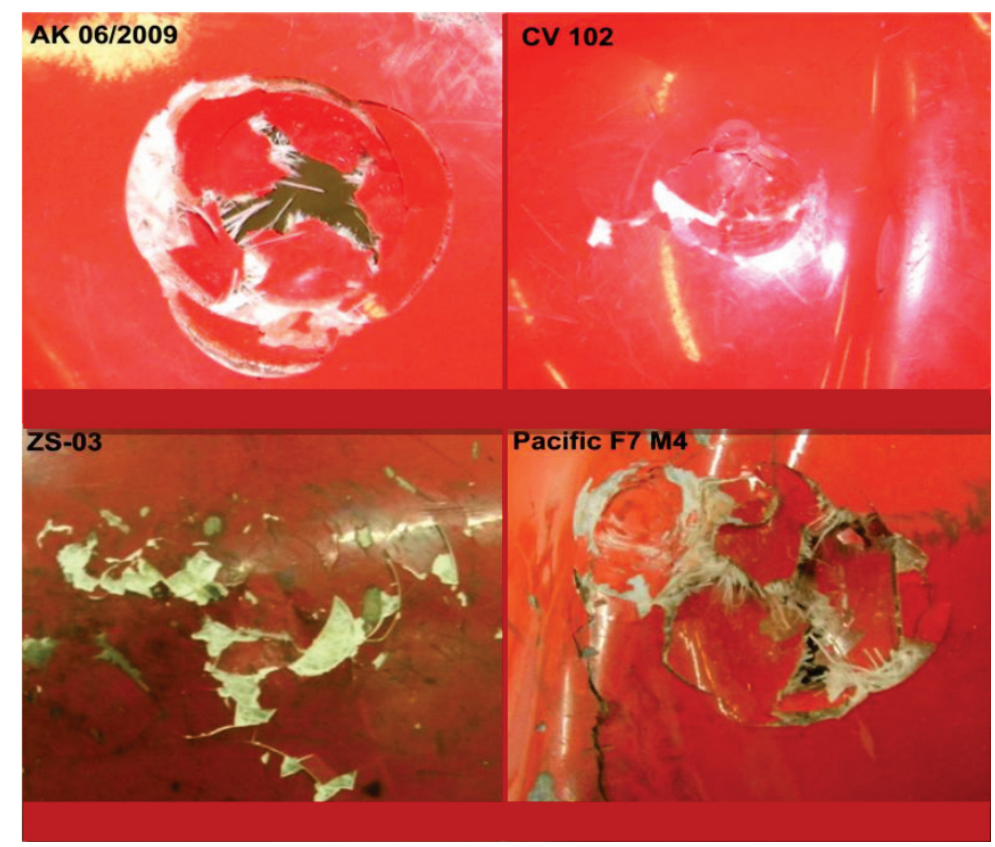

Fig. 4. Helmets shells failures at the striker

\section{Analysis of reliability test results}

The helmet's reliability has been defined as an absorption capacity of impact load assuming that the threshold values of passive forces cannot be exceeded. The reliability test results indicate that in all points of tested helmets the value of passive force equal $1000 \mathrm{~N}$ on a sensor placed under the head model (in the place of the neck spine) was obtained. The next load level, $2000 \mathrm{~N}$, was achieved in all points of helmets manufactured by KZPT. In the F7 M4 helmet, in one out of five points the level of passive force was not obtained. It is beneficial for the operational reliability of this helmet. The force of $3000 \mathrm{~N}$ according to the literature corresponded to the limit force value. Therefore, it is an important threshold range of the passive force value. All tested helmets produced by KZPT manufacturer achieved this value of passive force (in all points). For the F7 M4 helmet this value was 
obtained in two out of five points. The passive force threshold of $4000 \mathrm{~N}$ was achieved in four out of five points of the all KZPT helmets and in two out of five points of the F7 M4 helmet. The passive force threshold of $5000 \mathrm{~N}$ according to [2] reflects the beginning range of the critical forces. This level of force was obtained in three out of five points of the KZPT helmets and in two out of five points of the F7 M4 helmet.
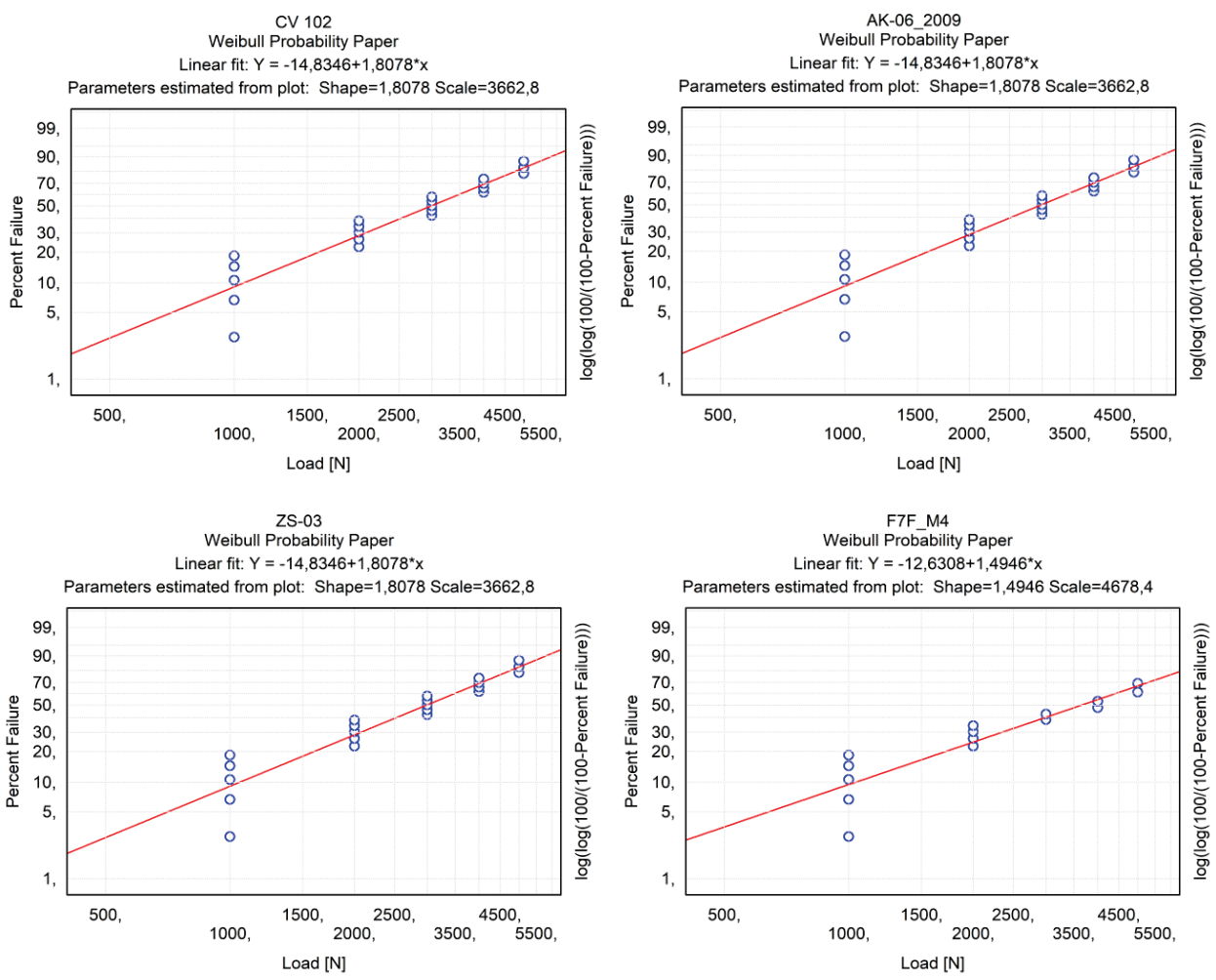

Fig. 5. Failure of helmets due to exceeding threshold values of passive forces

Reliability determines probability of object failure at a given time or other dimensions such as strength, traveled distance [11, 19]. In analysis a two-parameter Weibull distribution can be applied. A shape parameter is called Weibull modulus and corresponds to the slope of the probability plot. The highest value of the shape parameter the greater slope of the plot is. In the studies, the values of shape parameters in case of KZPT helmets were equal (fig. 5). They were higher than the value obtained to the F7 M4 helmet. It means that for the F7 M4 helmet there is lower probability of obtaining higher values of passive forces. The second Weibull distribution parameters is a scale parameter. This quantity is defined as a characteristic strength value of which $63.2 \%$ of the population will have failed. Like in case of the shape parameter, the same values of scale parameters were obtained to KZPT helmets (fig. 5). The F7 M4 helmet is characterized by the higher value of scale parameter. 


\section{Conclusions}

Based on the presented studies the main conclusions are as follows:

1. Firefighters' helmets used in Poland are designed to limit possibility of central contact between helmet's structure and head in order to prevent injuries. Probably, due to the same reason there is a redistribution of forces in the direction of the neck spine, which has been confirmed by the results of the studies.

2. Helmet's structure influences values of identified active and passive forces.

3. The majority of tested helmets exceeded the acceptable threshold values of passive force.

4. Reliability of firefighters' helmets regarding mechanical impacts occurring in operational conditions depends on the helmet's construction (shape and materials used). The evolution of ZS-03, AK-06, CV 102 helmets construction has not significantly affected their reliability in view of adopted criteria.

5. The structures of AK-06 and F7 M4 helmets were deeply penetrated by a striker. It should be considered as a very disadvantageous feature of these helmets.

\section{Acknowledgments}

We would like to thank Stawomir Bronisz, BEng, MSc. form Applied Mechanic Division of The Main School of Fire Service for help in carrying out the tests. Studies were based as of the project No. O ROB/0011/03/001 "Development of the innovative system of the research stand for personal protections studies”.

\section{References}

1. Abrate S.: Impact of laminated composite materials. Appl. Mech. Rev. Vol. 44, No. 4, 1991.

2. Baszczyński K.: The effect of temperature on the capability of industrial safety helmets to absorb impact energy. Engineering Failure Analysis, Vol. 46, 2014.

3. Bednarek Z., Drzymała T.: Zagrożenie występowania eksplozyjnego odpryskiwania betonu w czasie pożaru w tunelach komunikacyjnych. XIX Międzynarodowa Konferencja Naukowa Komputerowe Systemy Wspomagania Nauki, Przemysłu i Transportu „Transcomp 2015”, 2015.

4. Będziński R.: Biomechanika inżynierska: zagadnienia wybrane. Wyd. PWr, Wrocław 1997.

5. Demuts E., Sandhau R.S., Maddux G.E.: Barely visible damage threshold in graphite epoxy, Proc. Eight Int. Conf. on Composite Materials. SAMPE 1981. Vol. 4, 1981.

6. Hamouda A.M.S., Sohaimi R.M., Zaidi A.M.A., Abdullah S.: Materials and design issues for military helmets in Advances in Military Textiles and Personal Equipment. Woodhead Publishing, Cambridge 2012. 
7. Jackiewicz-Rek W., Drzymała T., Kuś A., Tomaszewski M.: Durability of high performance concrete (HPC) subject to fire temperature impact. Archives of Civil Engineering, Vol. LXII, 2016.

8. Jamroziak K.: Próba oceny urazu głowy w ochronie balistycznej miękkiej. Modelowanie Inżynierskie, Vol. 42, 2011.

9. Jankowski M., Kotełko M.: Doświadczalna identyfikacja związków fizycznych w piankach poliuretanowych. Przegląd Mechaniczny, No. 4, 2010.

10. Liu D., Chang C., Fan C., Hsu S.: Influence of environmental factors on energy absorption degradation of polystyrene foam in protective helmets. Engineering Failure Analysis, Vol. 10, 2003.

11. Melnik R., Koziak S., Sowiński B., Chudzikiewicz A.: Reliability analysis of metro vehicles operating in Poland. Transport Research Procedia, Vol. 40, 2019.

12. National Highway Traffic Safety Administration, Occupant Cash protection - head injury criterion. DC: NHTSA, Waszyngton 1972 (S6.2 of FMVSS 571.208).

13. Pawłowski K.: Rozprawa doktorska pt. „Systemy adaptacyjnej absorpcji obciążeń udarowych". Instytut Podstawowych Problemów Techniki. Warszawa 2011.

14. Pieniak D., Bronisz S., Kamocka-Bronisz R.: Badania redystrybucji sił przejmowanych przez hełm strażacki w kierunku kompresyjnym kręgosłupa szyjnego. Zeszyty Naukowe SGSP, No. 58, 2016.

15. Pieniak D., Walczak A., Kamocka-Bronisz R., Gil L.: Ocena doświadczalna pozostałej wytrzymałości i sztywności kompozytu polimerowego stosowanego w konstrukcji hełmów strażackich ze względu na temperaturę środowiska eksploatacji. TTS Technika Transportu Szynowego, No. 12, 2017.

16. PN-EN 443:2008: Helmets for firefighting in buildings and other structures.

17. Sawicki T.: Czynniki zagrażające bezpieczeństwu strażakom w warunkach pożaru. Bezpieczeństwo Pracy, No. 7-8, 2004.

18. Walczak A., Pieniak D., Naworol I., Wąsik W., Chudy P., Sutuła M.: Studies on absorptive properties of polymer foams used for manufacturing of firefighter helmets in Poland. Safety \& Fire Technology, Vol. 50, 2018.

19. Walczak A., Pieniak D., Niewczas A., Niewczas A.M., Kordos P.: Study of ceramicpolymer composites reliability based on the bending strength test. Journal of KONBiN. Vol. 35, 2015.

20. Wolański W., Tejszerska D.: Analiza numeryczna powstania urazów kręgosłupa szyjnego. Modelowanie Inżynierskie, Vol. 35, 2008. 